\title{
Kebijakan Deviden, Perputaran Persediaan Dan Perputaran Modal Kerja, Kebijakan Hutang dan Set Kesempatan Investasi
}

\author{
Putu Purnama Dewi ${ }^{1}$ \\ Helfrida Lila Man' \\ ${ }^{1,2}$ Fakultas Ekonomi dan Bisnis Universitas Pendidikan Nasional (Undiknas), \\ Bali , Indonesia \\ e-mail: purnamadewi@undiknas.ac.id
}

\begin{abstract}
ABSTRAK
Penelitian ini bertujuan untuk menguji pengaruh kebijakan deviden, perputaran persediaan dan perputaran modal kerja terhadap kebijakan hutang dengan set kesempatan investasi sebagai variabel moderating pada perusahaan manufaktur sektor aneka industri yang terdaftar di Bursa Efek Indonesia periode 2015 sampai 2017. Penelitian ini menggunakan metode purposive sampling yaitu penentuan jumlah sampel yang diambil secara acak berdasarkan kriteria-kriteria tertentu. Sampel yang memenuhi syarat adalah 10 perusahaan pada sektor aneka industri yang terdaftar di BEI tahun 2015 sampai 2017. Teknik analaisis data dengan menggunakan teknik regresi berganda.

Kata kunci: Kebijakan deviden, perputaran persediaan,perputaran modal kerja,set kesempatan investasi, kebijakan hutang.
\end{abstract}

\begin{abstract}
This study aims to exmine the effect of inventory turnover dividend policy and working capital turnover on debt policy with the investment opportunity set as a moderating variable in manufacturing companies of various industrialsectors listed on the Indonesia Stock Exchange for the period 2015 to 2017. This research uses purposive sampling method that is determining the number of samples taken randomly basedon certain criteria The eligible sample is 10 companies in the various industrial sector listed. Analysis data using multiple regression techniques.

Keywords: Dividend policy, inventory turnover, working capital turnover, investment opportunity set, debt policy.
\end{abstract}

\section{PENDAHULUAN}

Pertumbuhan ekonomi di Indonesia juga didorong dari dari adanya perusahaan manufaktur. Skala industri secara nasional tergambar dari permintaan yang besar dan hasil produksi dari perusahaan manufaktur. Keterkaitan pemegang saham terhadap perusahaan manufaktur merupakan tujuan utama dari setiap perusahaan manufaktur. Sejak tahun 2014 hingga tahun 2018 sekarang ini nilai tukar rupiah cenderung mengalami fluktuasi yang berimbas pada perekonomian Indonesia. Jika 
rupiah melemah maka perekonomian di Indonesia mengalami perlambatan yang cukup serius. Hal ini juga berdampak bagi kondisi perekonomian di dalam perusahaan manufaktur, yakni berdampak meningkatnya nilai impor bahan baku, peralatan dan mesin-mesin yang terjadi di perusahaan manufaktur. Hal seperti inilah yang juga menyebabkan perusahaan manufaktur membuat berbagai aktivitas untuk mengelola sumber dana lebih baik lagi agar tidak kalah pada persaingn pasar. Dengan adanya kebijakan hutang perusahaan akan mendapatkan tambahan dana dari luar perusahaan yang akan membantu pembiayaan operasional perusahaan. Perusahaan yang mengalami penurunan ekonomi sebaiknya melakukan kebijakan hutang. Keuntungan dari hutang bagi perusahaan adalah untuk membantu membesarkan usahanya karena pajak yang dibayarkan perusahaan yang berhutang cenderung kecil dibandingkan dengan perusahaan yang tidak memiliki hutang. Hutang juga mampu menjaga earning per share lebih besar yang akan membawa keuntungan bagi perusahaan. Laverage digunakan perusahaan untuk memperbesar return on investment dengan menggunakan pinjaman. Manajemen mengeluarkan kebijakan hutang merupakan cara yang baik untuk membesarkan perusahaan dalam waktu yang singkat, namun harus mempengaruhi kebijakan hutang adalah kebijakan deviden, profitabilitas, kepemilikan manajerial, kepemilikan institusional, ukuran perusahaan, pertumbuhan perusahaan, free cash flow, sturuktur aset, dan risiko bisnis.

Berdasarkan hasil tersebut penulis ingin menguji kembali pengaruh kebijakan deviden terhadap kebijakan hutang dikarenakan adanya ketidakkonsistenan hasil dari penelitian terdahulu. Sebagai kebaruan dari penelitian 
ini penulis menambahkan variabel perputaran persediaan dan perputaran modal serta menambahkan variabel moderasi yaitu set kesempatan investasi (SKI). Pemilihan variabel set kesempatan investasi dalam penelitian ini mengutip pernyataan (Kallapur Dan Trombly, 1999) bahwa set kesempatan investasi merupakan karakteristik penting perusahaan dan sangat mempengaruhi cara pandang manager, pemilik, investor dan kreditor terhadap perusahaan.(Adam Dan Goyal, 2006) juga mengatakan bahwa set kesempatan investasi mempunyai peranan yang penting dalam kebijakan keuangan perusahaan. Berbagai riset juga telah membuktikan bahwa nilai perusahaan yang tinggi yang dinyatakan dengan set kesempatan investasi cenderung mempengaruhi kebijakan perusahaan seperti pendanaan, dividen, akuntansi, kompensasi eksekutif, struktur modal dan sebagainya. (Karsana, Yusef Widya , 2004). Penambahan variabel set kesempatan investasi sebagai variabel moderasi dalam penelitian ini diharapkan dapat memperkuat hubungan antara kebijakan deviden, perputaran persediaan dan perputaran modal kerja terhadap kebijakan hutang.

Kebijakan dividen merupakan keputusan yang diambil perusahaan apakah akan membagikan laba yang diperoleh kepada para pemegang saham dalam bentuk dividen atau menyimpannya dalam bentuk laba ditahan. Kebijakan dividen merupakan keputusan strategis yang melibatkan dua kelompok kepentingan yang berbeda, yaitu pemegang saham dan manajemen. Kedua kelompok tersebut memandang dividen dengan kepentingannya masing- masing. Pemegang saham memandang dividen sebagai bentuk kompensasi atas kepemilikan terhadap saham perusahaan, sedangkan manajemen memandang 
Putu Purnama Dewi dan Helfrida Lila Man. Kebijakan ...

dividen sebagai pengurang potensial laba ditahan. Perputaran persediaan menunjukkan berapa kali persediaan diganti (dijual) dalam waktu satu tahun. Dengan demikian, tingkat perputaran persediaan yang tinggi mengindikasikan bahwa tingkat penjualan yang tinggi pada perusahaan. Dengan tingkat perputaran persediaan yang tinggi berarti risiko kerugian dan biaya terhadap persediaan dapat diminimalkan. Adapun perputaran persediaan menurut (Warren, 2005) adalah: Perputaran persediaan mengukur hubungan antara volume barang dagang yang dijual dengan jumlah persediaan yang dimiliki selama periode berjalan. Modal kerja selalu dalam keadaan berputar atau beroperasi dalam perusahaan selama perusahaan yang bersangkutan dalam keadaan usaha. Periode perputaran modal kerja (working capital turnorver period) dimulai saat kas diinvestasikan dalam komponen modal kerja sampai saat dimana kas kembali lagi menjadi kas. Makin pendek periode tersebut berarti makin cepat perputarannya atau makin tinggi tingkat perputarannya (turnorver rate-nya). Lama periode perputaran modal kerjanya tergantung kepada berapa lama periode perputaran dari masingmasing komponen dari modal kerja tersebut (Bambang Riyanto, 1995). (Myers, 1997) menyatakan bahwa investment opportunity set (IOS) is the extent to which firm value depends on future discretionary expenditures by the firm, yang diterjemahkan "set kesempatan investasi (SKI) adalah sejauh mana nilai perusahaan bergantung pada pengeluaran diskresioner masa depan"

Data perusahaan pada sektor aneka industri karena sektor aneka industri merupakan sektor yang secara lansung merasakan dampak dari perubahan ekonomi di Indonesia. Sektor aneka industri merupakan sektor yang rawan hancur 
ketika terjadi krisis karena krisis bisa melemahkan permintaan akan produk dari industri yang bisa berakibat kerugian bagi perusahaan di dalamnya. Namun ketika ekonomi meggeliat sektor ini juga akan mengikuti untuk menggeliat. Oleh karena itu berinvestasi di sektor ini bagus dilakukan ketika ekonomi bertumbuh dengan cepat.

Landasan teori yang digunakan dalam penelitian ini adalah teori pecking order yang menyatakan bahwa laba ditahan merupakan sumber dana internal yang utama, sedangkan laba eksternal yang utama merupakan hutang. Kebijakan hutang merupakan keputusan yang diambil oleh manajemen untuk menentukan besarnya hutang dalam sumber pendanaannya yang berguna untuk membiayai kegiatan operasional perusahaan. Selain itu kebijakan utang perusahaan juga berfungsi sebagai mekanisme monitoring terhadap tindakan manajer yang dilakukan dalam pengelolaan perusahaan (Bertha Firyanni Gusti, 2013).

\section{METODE PENELITIAN}

Variabel terikat dalam penelitian ini adalah kebijakan hutang (Y). Variabel bebasnya yaitukebijakan deviden (X1), perputaran persediaan (X2), perputaran modal kerja (X3) dan variabel moderatingnya adalah set kesempatan investasi (X4). Model Penelitian dapat ditujukan pada gambar 1. 


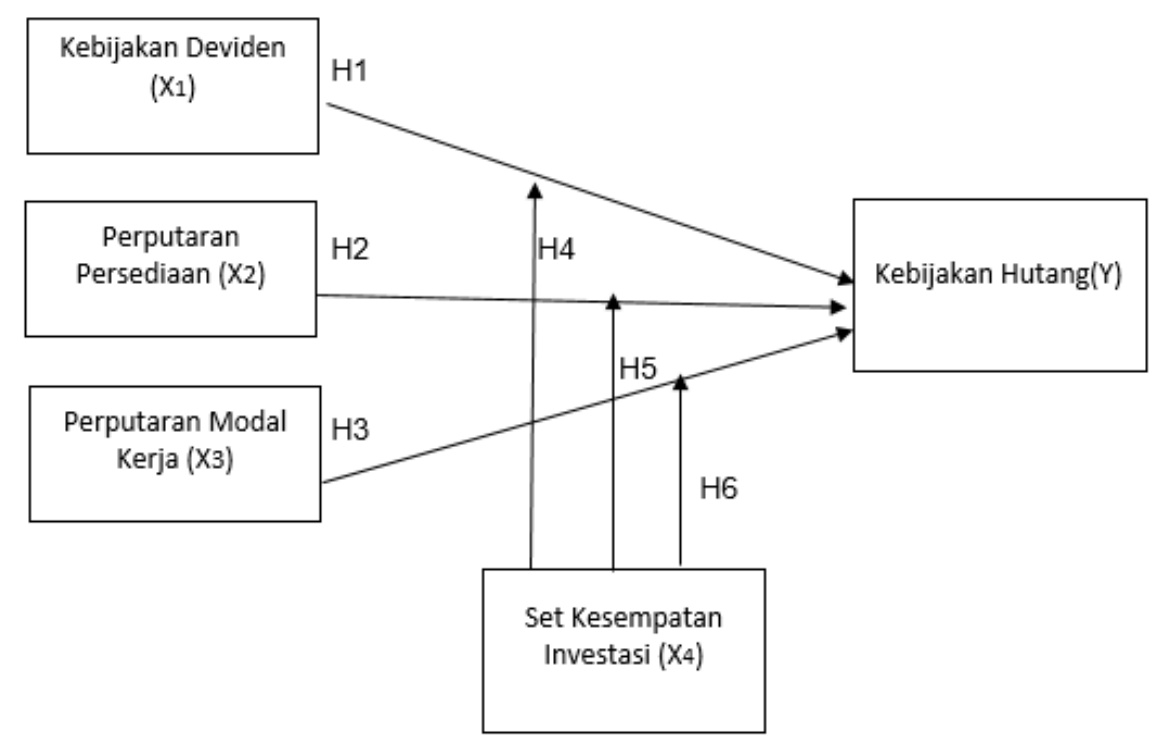

Gambar 1. Model Penelitian

Sumber : Data diolah, 2018

Terdapat 6 hipotesis dari penelitian ini yaitu

$\mathrm{H}_{1}$ : Kebijakan Deviden berpengaruh positif pada Kebijakan Hutang Persusahaan.

$\mathrm{H}_{2}$ :Perputaran Persediaan berpengaruh positif pada Kebijakan Hutang Perusahaan.

$\mathrm{H}_{3}$ :Perputaran Perputaran Modal Kerja berpengaruh positif pada Kebijakan Hutang Perusahaan.

$\mathrm{H}_{4}$ :Set Kesempatan Investasi mampu memoderasi hubungan antara kebijakan deviden dengan Kebijakan Hutang Perusahaan.

$\mathrm{H}_{5}$ :Set Kesempatan investasi mampu memoderasi hubungan antara Perputaran Persediaan dengan Kebijakan Hutang Perusahaan.

$\mathrm{H}_{6}$ :Set Kesempatan Investasi mampu memoderasi hubungan antara Perputaran Modal Kerja dengan Kebijakan Hutang Perusahaan.

Penelitian ini dilakukan pada perusahaan manufaktur yang terdapat di Bursa Efek Indonesia (BEI) periode 2015-2017 dengan mengambil data sekunder yang diakses di Bursa Efek Indonesia (BEI) melalui website resmi BEI berupa 
laporan keuangan. Populasi dalam penelitian ini adalah perusahaan manufaktur pada sektor aneka industri yang terdaftar pada Bursa Efek Indonesia (BEI) pada tahun 2015-2017. Sampel dalam penelitian ini adalah perusahaan manufaktur di Bursa Efek Indonesia (BEI) pada tahun 2015 - 2017. Pemilihan sampel menggunakan metode purposive sampling, yaitu menggunakan kriteria tertentu sesuai berdasarkan pertimbangan tertentu dan tujuan peneliti yaitu: Perusahaan yang dipilih dalam bentuk sektor aneka industri yang terdaftar di Bursa Efek Indonesia untuk periode 2015-2017, laporan keuangan perusahaan dalam sektor aneka industri yang dapat diakses, laporan keuangan perusahaan dalam sektor aneka industri disajikan dalam mata uang rupiah. Laporan keuangan yang menggunakan mata uang selain rupiah dikeluarkan karena jika akan dikonversikan menggunakan kurs, maka kurang menggambarkan keadaan perusahaan dikarenakan kurs selalu berfuktuasi setiap harinya.

Jenis data yang digunakan dalam penelitian ini adalah kuantitatif. Sumber dan jenis data yang digunakan dalam penelitian ini adalah data sekunder. Dalam Penelitian ini, teknik pengumpulan data yang digunakan adalah studi dokumentasi. Data yang digunakan berupa data laporan keuangan publikasi tahun 2015-2017 yang berhubungan dengan variabel yang diteliti.

\section{HASIL DAN PEMBAHASAN}

Statistik deskriptif ini memberikan gambaran mengenai nilai minimum, nilai maksimum, mean, serta standar deviasi. Hasil lengkapnya dapat dilihat pada tabel berikut ini. 
Tabel 1.

Hasil Statistik Deskriptif

\begin{tabular}{lccccc}
\hline & $\mathrm{N}$ & Minimum & Maximum & Mean & $\begin{array}{c}\text { Std. } \\
\text { Deviasi }\end{array}$ \\
\hline DPR & 30 & .00 & 3.68 & .3966 & .71363 \\
$\mathrm{IN}$ & 30 & .29 & 329.65 & 50.482 & 36.51 \\
$\mathrm{WCT}$ & 30 & .00 & 221.58 & 17.601 & 15.79 \\
SKI & 30 & .08 & 6.09 & 1.48 & 1.392 \\
DER & 30 & .34 & 2.82 & 1.384 & .810 \\
Valid N (listwise) & 30 & & & & \\
\hline \multicolumn{2}{c}{ Sumber $:$ Data }
\end{tabular}

Sumber : Data diolah, 2018

Berdasarkan statistik deskriptif sesuai dengan Tabel 1 diperoleh nilai minimum sebesar 0,0 sedangkan nilai maksimum sebesar 3,68. Nilai rata-rata dari kebijakan deviden sebesar 0,39 dan standar deviasi sebesar 0,71. Peputaran persediaan (IN). Berdasarkan statistik deskriptif sesuai dengan Tabel 1 diperoleh nilai minimum sebesar 0,29 sedangkan nilai maksimum sebesar 329,65. Nilai rata-rata dari perputaran persediaan sebesar 50,48 dan standar deviasi sebesar 36,51 .

Berdasarkan statistik deskriptif sesuai dengan Tabel 1 diperoleh nilai minimum sebesar 0,00 sedangkan nilai maksimum sebesar 221,58 . Nilai rata-rata dari perputaran persediaan sebesar 17,60 dan standar deviasi sebesar 15,79.

Berdasarkan statistik deskriptif sesuai dengan Tabel 1 diperoleh nilai minimum sebesar 0,08 sedangkan nilai maksimum sebesar 6,09. Nilai rata-rata dari set kesempatan investasi sebesar 1,48 dan standar deviasi sebesar 1,39.

Berdasarkan statistik deskriptif sesuai dengan Tabel 1 diperoleh nilai minimum sebesar 0,34 sedangkan nilai maksimum sebesar 2,82. Nilai rata-rata dari kebijakan hutang sebesar 1,38 dan standar deviasi sebesar 0,81.Uji asumsi 
klasik tujuannya adalah untuk membuktikan bahwa asumsi klasik pada model regresi terpenuhi, maka perlu dilakukan uji asumsi klasik sebagai berikut.

Tabel 2. Nilai Uji Normalitas

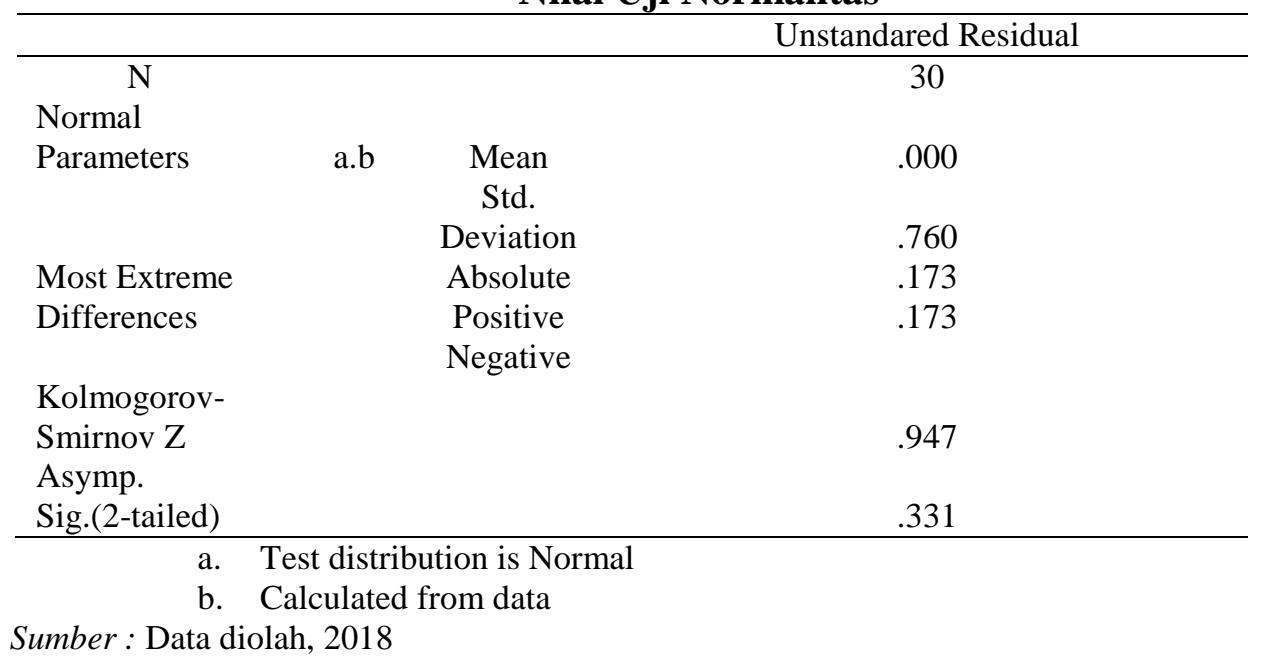

Berdasarkan output SPSS diperoleh nilai Asymp. Sig. (2-tailed) 0,331 yang lebih besar dari 0,05. Hal itu berarti residual data berdistribusi normal.

Tabel 3.

Nilai Tolerance dan VIF

\begin{tabular}{ccc}
\hline & Coefficients $^{\text {a }}$ & \\
\hline Model & Tolerance & Collinearity Stastistics \\
DPR & 993 & 1.007 \\
IN & 996 & 1,014 \\
WCT &, 989 & 1,011 \\
\hline ber $:$ Data diolah, 2018 & &
\end{tabular}

Sumber : Data diolah, 2018

Berdasarkan output SPSS diperoleh nilai tolerance DPR sebesar 0,993, IN sebesar 0,986, WCT sebesar 0,989 yang yang lebih besar dari 10 persen $(0,10)$, dan nilai VIF variabel DPR 1,007, variabel IN sebesar 1,014 dan variabel WCT sebesar 1,011 yang lebih kecil dari 10. Hal ini berarti model regresi tersebut lolos uji multikolinearitas. 
Tabel 4.

Uji Heteroskedasitas

\begin{tabular}{|c|c|c|c|c|c|c|}
\hline \multicolumn{2}{|c|}{ Model } & \multicolumn{3}{|c|}{ Std. } & $\mathrm{t}$ & Sig. \\
\hline \multirow[t]{4}{*}{1} & (Constant) & ,625 & , 100 & & 6,241 & ,000 \\
\hline & DPR &,- 049 & , 104 &,- 090 &,- 468 & ,643 \\
\hline & IN & ,001 & ,001 & ,182 & ,944 & ,354 \\
\hline & WCT & ,000 & ,002 & ,025 & ,131 & 897 \\
\hline
\end{tabular}

a. Dependent Variable : Abres

Sumber : Data diolah, 2018

Hasil uji Gletser diperoleh nilai signifikansi variabel DPR sebesar 0,643, IN

sebesar 0,354, dan WCT sebesar 0,897 semua nilai sig pada ketiga variabel bebas lebih besar dari 0,05. Hal ini berarti model regresi tersebut tidak mengandung gejala heteroskedastisitas.

Tabel 5.

Uji Autokorelasi

\begin{tabular}{|c|c|c|c|c|c|}
\hline Model & $\mathrm{R}$ & R Square & $\begin{array}{l}\text { Adjusted } \\
\text { R Square }\end{array}$ & $\begin{array}{l}\text { Std. Error of } \\
\text { the Estimate }\end{array}$ & $\begin{array}{l}\text { Durbin- } \\
\text { Watson }\end{array}$ \\
\hline 1 &, $690^{a}$ & ,476 & ,214 & 09197 & 1,938 \\
\hline
\end{tabular}

a. Predictors: (Constant), ROA, Pertumbuhan. Asset, Risiko.bisnis

b. Dependent Variable: DER

Sumber : Data diolah, 2018

Nilai Durbin-Watson adalah sebesar 1,873, dengan mengacu pada teori menurut Nugroho (2010) yaitu apabila nilai Durbin Watson mendekati nilai 2 berarti tidak terjadi autokorelasi pada model regresi.

Analisis ini diolah dengan program computer Statistical Package for Social Sciences (SPSS) versi 22 pengaruh kebijakan deviden, perputaran persediaan dan perputaran modal kerja terhadap kebijakan hutang dapat dianalisis menggunakan perhitungan regresi linier berganda. Berikut rangkuman hasil regresi linier berganda. 
Tabel 6.

Regresi Linear Berganda

\begin{tabular}{lcccccc}
\hline Model & & Std. & & & \\
\hline 1 & (Constant) & 1,295 &, 204 & & 6,355 &, 000 \\
& DPR &, 313 &, 121 &, 276 & 2,586 &, 025 \\
& IN &, 012 &, 003 &, 127 & 3,435 &, 012 \\
& WCT & 0,001 &, 001 &, 084 & 2,491 &, 027 \\
\hline
\end{tabular}

a. Dependent Variable: DER

Sumber : Data diolah, 2018

Secara matematis tabel 6 dapat digambarkan sebagai berikut :

$$
\mathrm{Y}=1,295+0,313 \mathrm{X}_{1}+0,012 \mathrm{X}_{2}+0,001 \mathrm{X}_{3}
$$

Nilai konstanta sebesar 1,295 artinya apabila kebijakan deviden, perputaran persediaan dan perputaran modal kerja dianggap konstan mak besarnya kebjiakan hutang sebesar 1,295. Nilai koefisien regresi kebijakan deviden $=0,313$, secara statistik menunjukkan bahwa ada pengaruh positif variabel kebijakan deviden terhadap kebijakan hutang. Nilai koefisien sebesar 0,313 memiliki arti jika kebijakan deviden naik sebesar 1 persen, maka nilai kebijakan hutang naik sebesar 0,313 persen dengan asumsi variabel lain konstan. Nilai koefisien regresi perputaran persediaan $=0,012$, secara statistik menunjukkan bahwa ada pengaruh positif variabel perputaran persediaan terhadap kebijakan hutang. Nilai koefisien sebesar 0,012 memiliki arti jika perputaran persediaan naik sebesar 1 persen, maka nilai kebijakan hutang naik sebesar 0,012 persen dengan asumsi variabel lain konstan. Nilai koefisien regresi perputaran modal kerja $=0,001$, secara statistik menunjukkan bahwa ada pengaruh positif variabel perputaran modal kerja terhadap kebijakan hutang. Nilai koefisien sebesar 0,001 memiliki arti jika kebijakan hutang naik sebesar 1 persen, maka nilai perputara kebijakan hutang naik sebesar 0,001 persen dengan asumsi variabel lain konstan. 
Untuk menguji pengaruh moderasi set kesempatan investasi pada pengaruh kebijakan deviden, perputaran persediaan dan perputaran modal kerja terhada kebijakan hutang digunakan uji moderated regression analysis (MRA). Hasil pengujian ditunjukkan pada tabel berikut.

Tabel 7.

Hasil Pengujian MRA

\begin{tabular}{llccccc}
\hline Model & & B & Std. Eror & Betta & t & Sig. \\
\hline 1 & (Constant) & 1,486 &, 284 & & 5,229 &, 000 \\
& DPR &, 630 &, 378 &, 555 & 2,282 &, 038 \\
& IN &, 008 &, 004 &, 813 & 2,779 &, 025 \\
& WCT &, 005 &, 005 &, 309 & 2,782 &, 024 \\
& SKI &, 046 &, 242 &, 085 & 3,232 &, 085 \\
& DPR.SKI &, 371 &, 485 &, 390 & 3,059 &, 019 \\
& IN.SKI &, 004 &, 002 &, 725 & 3,197 &, 018 \\
& WCT.SK &, 006 &, 004 &, 442 & 2,941 &, 020 \\
\hline
\end{tabular}

a. Dependent Variable: DER

Sumber : Data diolah, 2018

$\mathrm{Y}=1,486+0,631 \mathrm{DPR}+0,008 \cdot \mathrm{IN}+0,005 \cdot \mathrm{WCT}+0,046 \cdot \mathrm{SKI}+0,371 \mathrm{DPR} * \mathrm{SKI}$ $+0,004 \mathrm{IN} * \mathrm{SKI}+0,006 \mathrm{WCT} * \mathrm{SKI}$

Tabel 7, menunjukkan bahwa tiga variabel independen yang dimasukkan dalam regresi dan satu variabel moderat, didapat variabel moderat (interaksi kebijakan deviden dan set kesempatan investasi, perputaran persediaan dan set kesempatan investasi, perputaran modal kerja dengan set kesempatan investasi) berpengaruh positif dan signifikan terhadap kebijakan hutang.

Variabel kebijakan deviden memberikan nilai parameter 0,630 variabel moderat yang merupakan interaksi antara kebijakan deviden dengan set kesempatan investasi dengan nilai parameter 0,71 dan nilai sig 0,019 sehingga dapat disimpulkan bahwa variabel set kesempatan investasi merupakan variabel moderating. 
Variabel perputaran persediaan memberikan nilai parameter 0,008 variabel moderat yang merupakan interaksi antara perputaran persediaan dengan set kesempatan investasi dengan nilai parameter 0,008 dan nilai sig 0,018 sehingga dapat disimpulkan bahwa variabel set kesempatan investasi merupakan variabel moderating.

Variabel perputaran modal kerja memberikan nilai parameter 0,005 variabel moderat yang merupakan interaksi antara modal kerja dengan set kesempatan investasi dengan nilai parameter 0,006 dan nilai sig 0,020 sehingga dapat disimpulkan bahwa variabel set kesempatan investasi merupakan variabel moderating.

Analisis ini digunakan untuk mengetahui besarnya kontribusi kebijakan deviden, perputaran persediaan dan perputaran modal kerja terhadap kebijakan hutang yang dinyatakan dalam persentase, dengan rumus $D=R^{2} \times 100 \%$

\section{Tabel 8.}

\section{Koefisien Determinasi}

\begin{tabular}{|c|c|c|c|c|c|}
\hline Model & $\mathrm{R}$ & R Square & $\begin{array}{l}\text { Adjusted } \\
\text { R Square }\end{array}$ & $\begin{array}{l}\text { Std. Error of } \\
\text { the Estimate }\end{array}$ & $\begin{array}{l}\text { Durbin- } \\
\text { Watson }\end{array}$ \\
\hline 1 &, $629^{a}$ & ,396 &, 356 & ,80815 & 1,873 \\
\hline
\end{tabular}

a. Predictors: (Constant), WCT,DPR,IN

b. Dependent Variable: DER

Sumber : Data diolah, 2018

Berdasarkan Tabel 8 diperoleh besarnya koefisien determinasi (adjusted $\mathrm{R}^{2}$ ) sebesar 0,356 atau 35,6\% ini menunjukkan pengaruh kebijakan deviden, perputaran persediaan dan perputaran modal kerja memberikan kontribusi naik turunnya kebijakan hutang sebesar 35,6 dan 64,4\% disebabkan oleh faktor lain yang tidak dibahas dalam penelitian ini. 


\section{HASIL DAN PEMBAHASAN}

Pengujian pengaruh kebijakan deviden terhadap kebijakan hutang, secara parsial dilakukan melalui uji t, yaitu dengan membandingkan nilai signifikansi t dengan $\alpha$ $(0,05)$. Besar t hitung variabel kebijakan deviden dengan nilai sig $0,025<\alpha(0,05)$ yang berarti penolakan $\mathrm{H}_{0}$ sehingga $\mathrm{H}_{1}$ diterima. Yang berarti kebijakan deviden berpengaruh positif signifikan terhadap kebijakan hutang.

Kebijakan deviden dipandang berbeda oleh pemegang saham dan manajemen perusahaan. Bagi pemegang saham deviden merupakan kompensasi kepemilikan terhadap saham perusahaan sedangkan bagi manajemen perusahaan deviden merupakan pengurangan laba ditahan. Jika di dalam perusahaan mengalami penurunan ekonomi yang diakibatkan karena masalah global maka akan berdampak pula bagi laba perusahaan. Perusahaan harus tetap membayar deviden kepada pemegang saham walaupun kondisi ekonominya sedang menurun. Pembayaran deviden tersebut akan mengurangi laba sehingga perusahaan akan mengalami kesulitan dalam membiayai operasional perusahaan. Maka manajemen perusahaan kemudiaan mengeluarkan kebijakan hutang guna untuk menambah laba perusahaan agar perusahaan tetap beroperasional secara efektif. Teori pecking order menyatakan bahwa apabila sumber dana internal perusahaan tidak mencukupi perusahaan akan menggunakan sumber dana eksternal mulai dari yang paling kecil resikonya yaitu hutang. Perusahaan yang membagikan deviden dalam jumlah besar akan memerlukan tambahan dana untuk membiayai investasinya melalui hutang, sehingga kebijakan deviden mempengaruhi hutang secara searah. 
ISSN: 2302-8556

E-Jurnal Akuntansi Universitas Udayana

Vol.26.3.Maret (2019): 2353 -2374

Hasil peneitian ini bersesuaian dengan penelitian Nuraini, Adibah (2016) tentang Pengaruh Kepemilikan Manajerial, Kepemilikan Institusional, Kebijakan Dividen, dan Profitabilitas terhadap Kebijakan Hutang (Studi pada Perusahaan Properti dan Real Estate yang Terdaftar di BEI Periode 2010-2014), dengan menggunakan sampel 48 perusahaan properti dan real estate menemukan bahwa kebijakan dividen berpengaruh positif terhadap kebijakan hutang.

Pengujian ini dilakukan secara parsial yaitu dengan melakukan uji t, yaitu dengan membandingkan nilai signifikansi t dengan $\alpha(0,05)$. Besar $\mathrm{t}$ hitung variabel perputaran persediaan dengan nilai sig $0,012<\alpha(0,05)$ yang berarti penolakan $\mathrm{H}_{0}$ sehingga $\mathrm{H}_{2}$ diterima. Hal ini berarti bahwa perputaran persediaanberpengaruh positif signifikan terhadap kebijakan hutang.

Pada prinsipnya semua perusahaan yang melaksanakan proses produksi akan menyelenggarakan persediaan bahan baku untuk kelangsungan proses produksi dalam perusahaan tersebut.Jika dalam perusahaan mengalami masalah ekonomi sebagai akibat dari persaingan maupun fenomena global yang terjadi misalnya rendahnya nilai tukar rupiah maka akan mempengaruhi harga persediaan bahan baku yang dibutuhkan perusahaan. Tetapi untuk tetap melaksanakan proses produksi perusahaan akan tetap mendatangkan bahan baku tersebut dalam jumlah besar maupun kecil. Peristiwa ini akan mempengaruhi kondisi ekonomi perusahaan yaitu berkurangnya dana perusahaaan. Sumber dana internal saja tidak mencukupi untuk membiayai kegiatan operasional perusahaan maka, manajemen perusahaan akan menggunakan kebijakan hutang guna untuk menutupi kurangnya dana perusahaan sesuai dengan teori pecking order. 
Putu Purnama Dewi dan Helfrida Lila Man. Kebijakan ...

Hasil pengujian variabel ini ditunjukkan melalui membandingkan besarnya t hitung variabel peprutaran modal kerja dengan nilai sig yaitu $0,027<\alpha(0,05)$ yang berarti penolakan $\mathrm{H}_{0}$ sehingga $\mathrm{H}_{3}$ diterima. Ini berarti bahwa perputaran modal kerjaberpengaruh positif signifikan terhadap kebijakan hutang.

Modal kerja mampu membiayai pengeluaran atau operasi perusahaan sehari-hari. Dengan modal kerja yang cukup akan membuat perusahaan beroperasi secara ekonomis dan efisien serta tidak mengalami kesulitan keuangan perusahaan. Jika suatu perusahaan mengalami volume pejualan yang rendah serta mengalami fluktuasi dalam penjualan yang disebabkan oleh faktor musim maka akan mempengaruhi kebutuhan modal kerja perusahaan. Perusahaan yang memiliki modal kerja rendah akan mempengaruhi tingkat perputarannya sehingga menghambat kinerja perusahaan yang akan mengakibatkan kurangnya modal untuk membiayai gaji, upah dan biaya operasional lainnya. Maka, manajemen perusahaan akan mengeluarkan kebijakan hutang guna untuk mendapatkan dana eksternal yang kemudian akan memenuhi kebutuhan modal kerja perusahaan.

Variabel kebijakan deviden memberikan nilai parameter 0,630 variabel moderat yang merupakan interaksi antara kebijakan deviden dengan set kesempatan investasi dengan nilai parameter 0,71 dan nilai sig 0,019 sehingga dapat disimpulkan bahwa variabel set kesempatan investasi mampu memoderasi hubungan antara kebijakan deviden dengan kebijakan hutang.

Perusahaan dengan set kesempatan investasi yang tinggi menunjukkan bahwa nilai perusahaan lebih banyak ditentukan oleh aktiva yang tidak berwujud sehingga akan cenderung kesulitan untuk mendapatkan hutang dari pihak luar 
Myers (1977). Hal ini dikarenakan perusahaan kurang memiliki aset riil yang dapat digunakan sebagai jaminan hutang. Sebaliknya, perusahaan yang memiliki level set kesempatan investasi yang lebih rendah akan mudah untuk memperoleh pinjaman dari pihak luar karena perusahaan dengan set kesempatan investasi rendah menunjukkan bahwa nilai perusahaan lebih banyak ditentukan oleh aset riilnya yang dapat dijadikan sebagai jaminan untuk memperoleh hutang.

Tinggi rendahnya set kesempatan investasi (SKI) dapat ikut menentukan kuatnya lemah hubungan antara dividen dengan hutang perusahaan, karena SKI dapat mempengaruhi kebijakan pendanaan perusahaan dan kemampuan perusahaan untuk akses ke penyedia dana (lender). Kebijakan dividen melibatkan keputusan untuk membayar dividen atau menahan dividen tersebut untuk reinvestasi dalam perusahaan. Pembayaran dividen yang besar kepada pemegang saham mengakibatkan dana yang dapat digunakan oleh perusahaan untuk investasi menjadi rendah. Hal tersebut dikarenakan laba yang diperoleh perusahaan dialokasikan untuk pembayaran dividen daripada laba ditahan sehingga menyebabkan dana yang dibutuhkan untuk investasi menjadi berkurang atau kecil. Untuk menghadapi peluang investasi yang semakin meningkat maka perusahaan membutuhkan dana tambahan dari luar yaitu hutang.

Penelitian bersesuaian dengan Ganeswari, Rr. Dyah Arum (2007) tentang Pengaruh Set Kesempatan Investasi pada Hubungan Antara Kebijakan Dividen dan Aliran Kas Bebas dengan Tingkat Leverage pada Perusahaan Manufaktur, dengan menggunakan sampel 59 perusahaan periode 2003-2005 menemukan set 
kesempatan investasi mampu memoderasi hubungan antara kebijakan dividen terhadap kebijakan hutang.

Variabel perputaran persediaan memberikan nilai parameter 0,008 variabel moderat yang merupakan interaksi antara perputaran persediaan dengan set kesempatan investasi dengan nilai parameter 0,008 dan nilai sig 0,018 sehingga dapat disimpulkan bahwa variabel set kesempatan investasi mampu memoderasi hubungan antara perputaran persediaan dengan kebijakan hutang.

Persediaan yang tinggi bagi perusahaan memerlukan dana yang besar, dengan dana internal saja tidaklah cukup untuk membiayai persediaan dalam jumlah yang besar. Bahkan bila perusahaan menggunakan seluruh dana internalnya saja akan berakibat buruk bagi perusahaan itu sendiri. Maka manajer mengeluarkan kebijakan hutang sebagai cara untuk mendapatkan biaya tambahan. Selanjutnya perusahaan kegiatan operasional perusahaan akan berjalan dengn lancar dan mendapatkan keuntungan yang tinggi sekaligus dapat mendongkrak nilai perusahaan, jika demikian maka perusahaan dapat membuka peluang bagi investor untuk berinvestasi pada perusahaannya.

Variabel perputaran modal kerja memberikan nilai parameter 0,005 variabel moderat yang merupakan interaksi antara modal kerja dengan set kesempatan investasi dengan nilai parameter 0,006 dan nilai sig 0,020 sehingga dapat disimpulkan bahwa variabel set kesempatan investasi mampu memoderasi hubungan antara perputaran modal kerja dengan kebijakan hutang.

Perusahaan yang memiliki modal kerja yang cukup akan dapat meningkatkan efisiensi serta tidak mengalami kesulitan keuangan perusahaan. 
Jika suatu perusahaan mengalami volume pejualan yang rendah serta mengalami fluktuasi dalam penjualan yang disebabkan oleh faktor musim maka akan mempengaruhi kebutuhan modal kerja perusahaan. Maka, manajemen perusahaan akan mengeluarkan kebijakan hutang guna untuk mendapatkan dana eksternal yang kemudian akan memenuhi kebutuhan modal kerja perusahaan.

Perputaran modal kerja yang baik dalam perusahaan membantu investor untuk memprediksi arus kas dikemudian hari, yaitu dipandang dari jumlah perputaran persediaan sebagai faktor utama yang akan mendukung arus kas dan perputaran persediaan yang akan dijual dikemudian hari dan akan mempengaruhi arus kas keluar. Perputaran modal kerja yang baik akan menentukan profit pada suatu perusahaan sehingga dapat membuka peluang investasi bagi investor.

\section{SIMPULAN}

Kebijakan deviden berpengaruh positif dan signifikan terhadap kebijakan hutang. Perputaran persediaan berpengaruh positif dan signifikan terhadap kebijakan hutang. Perputaran modal kerja berpengaruh positif dan signifikan terhadap kebijakan hutang. Set Kesempatan Investasi mampu memoderasi hubungan antara kebijakan deviden dengan Kebijakan Hutang Perusahaan. Set Kesempatan investasi mampu memoderasi hubungan antara Perputaran Persediaan dengan Kebijakan Hutang Perusahaan. Set Kesempatan Investasi mampu memoderasi hubungan antara Perputaran Modal Kerja dengan Kebijakan Hutang Perusahaan 


\section{REFERENSI}

Adam, T, dan Goyal. 2006. The Investment Opportunity Set and its Proksi Variables: Theory and Evidence, JEL Classification.

Arief, Bramantyo. 2011, “Analisis Pengujian Teori Pecking Order Melalui Keterkaitan Profitabilitas, Struktur Aset, Ukuran Perusahaan, dan Kesempatan Bertumbuh terhadap Financial Leverage Periode 2006-2009”, Universitas Diponegoro Semarang.

Arieska, Metha \& Barbara Gunawan, 2011, "Pengaruh Aliran Kas Bebas dan Keputusan Pendanaan terhadap Nilai Pemegang Saham dengan Set Kesempatan Investasi dan Dividen Sebagai Variabel Moderasi," Jurnal Akuntansi Dan Keuangan, Vol. 13, No. 1, Mei 2011 : 13-23.

Bambang Riyanto. 1995. Dasar-Dasar Pembelanjaan Perusahaan. Yogyakarta: BPFE-Yogyakarta.

Beny. 2013, "Pengaruh Dividend Payout, Profitabilitas, Pertumbuhan Perusahaan, Kepemilikan Manajerial, Kepemilikan Institusional dan Aliran Kas Bebas terhadap Kebijakan Hutang”, Jurnal Bisnis dan Akuntansi, Volume 15, Nomor 2, Desember 2013.

Brigham, E. F dan Houston, 2006. Dasar-dasar Manajemen Keuangan, Edisi Sepuluh, Alih Bahasa Ali Akbar Yulianto, Penerbit Salemba Empat, Jilid I, Jakarta.

Ganeswari, Rr. Dyah Arum, 2007. Pengaruh Set Kesempatan Investasi Pada Hubungan antara Kebijakan Deviden Dan Aliran Kas Bebas Dengan Tingkat Laverage, Yogyakarya: Universitas Gadjah Mada.

Gaver J. Jennifer., dan Keneth M. Gaver. 1993. Additional Evidence on the Association betweem the Investment Opportunity Set and Corporate Financing, Dividend, and Compenastion Policies. Journal Of Accounting anda Economics 16:125-160.

Ghozali \& Chariri, 2014. Teori Akuntansi (edisi empat), Semarang: Badan Penerbit Universitas Diponegoro.

Ghozali, Imam, 2011. Aplikasi Analisis Multivariate dengan Program IBM SPSS 19 (edisi kelima), Semarang: Badan Penerbit Universitas Diponegoro.

Gusti, Bertha Firyanni, 2013. "Pengaruh Free Cash Flow dan Struktur Kepemilikan Saham terhadap Kebijakan Hutang dengan Investment $O p$ portunity Set sebagai Variabel Moderating", Unversitas Negeri Padang, Padang. 
Hardiningsih, P dan Rachmawati. 2012. Determinan Kebijakan Hutang (Dalam Agency Theory Dan Pecking Order Theory). Dinamika Akuntansi, Keuangan dan Perbankan. Universitas Stikubank. 1(1). hal 11-24.

Indahningrum, R. Putri dan Ratih Handayani. 2009, "Pengaruh Kepemilikan Manajerial, Kepemilikan Institusional, Dividen, Pertumbuhan Perusahaan, Free Cash Flow dan Profitabilitas terhadap Kebijakan Hutang Perusahaan”, Jurnal Bisnis dan Akuntansi vol.11. No.3: 189-207.

Indriantoro,N. dan B.Supomo. 1999. "Metodologi Penelitian Bisnis Untuk Akuntansi Dan Manajemen”. Edisi Pertama. Yogyakarta: BPFE.

Jensen, Michael and William Meckling. 1976, "Theory Of The Firm: Managerial Behavior, Agency Costs and Ownership Structure", Journal of Financial Economics 3, 305-360.

Junaidi, Akhmad Afif. 2011, "Analisis Pengaruh Free Cash Flow, Struktur Kepemilikan, Kebijakan Dividen, Struktur Aktiva, dan Profitabilitas terhadap Kebijakan Hutang Perusahaan", Jurnal Fakultas Ekonomi dan Bisnis Universitas Dian Nuswantoro.

Kallapur, Sanjay and Trombley Mark. A. 1999, "The Association Between Investment Opportunity Set Proxies and Realized Growth", Journal of Business \& Accounting 26, April/May. P. 505-519.

Karsana, Yusef Widya. 2004, “Analisis Moderasi Set Kesempatan Investasi terhadap Hubungan Antara Kebijakan Dividen dan Aliran Kas Bebas dengan Tingkat Leverage Perusahaan”, Magister Manajemen UGM.

Kasmir. 2008. Analisis Laporan Keuangan. Jakarta: Rajawali Pers.

Larasati, Eva. 2011, "Pengaruh Kepemilikan Manajerial, KepemilikanInstitusional dan Kebijakan Dividen terhadap Kebijakan HutangPerusahaan", Jurnal Ekonomi Bisnis, Vol.16, No, 2.

Myers, S. 1997. Determinant of Corporate Borrowing. Journal of financial economics.

Nuraini, Adibah. 2016, "Pengaruh Kepemilikan Manajerial, Kepemilikan Institusional, Kebijakan Dividen, dan Profitabilitas terhadap Kebijakan Hutang (Studi Pada Perusahaan Properti dan Real Estate yang Terdaftar di BEI Periode 2010-2014)", Universitas Muhammadiyah Yogyakarta

Sugiyono, 2010, MetodePenelitian Kuantitatif dan RND. Bandung : Alfabeta. 
Putu Purnama Dewi dan Helfrida Lila Man. Kebijakan ...

Tarjo dan Jogiyanto. 2003, “Analisis Free Cash Flow dan Kepemilikan Manajerial terhadap Kebijakan Utang pada Perusahaan Publik di Indonesia, Simposium Nasional Akuntansi VI, Surabaya.

Warren. 2005. Pengantar Akuntansi, Edisi 21, Penerbit Salemba Empat Jakarta 